\title{
Retraction Note: Method development, validation, and stability studies of teneligliptin by RP-HPLC and identification of degradation products by UPLC tandem mass spectroscopy
}

\author{
T. N. V. Ganesh Kumar ${ }^{1 *}$, S. Vidyadhara', Niteen Ashok Narkhede ${ }^{2}$, Y. Sai Silpa ${ }^{1}$ and M. Rajya Lakshmi ${ }^{1}$
}

Retraction Note: Journal of Analytical Science and Technology (2016) 7:18.

https://doi.org/10.1186/s40543-016-0099-0

After publication, it came to the editor's attention that this manuscript [1] was inadvertently published before the peer review process was complete. The final version of this manuscript was published later as [2]. Springer Nature apologises to readers. Author T. N. V. Ganesh Kumar stated on behalf of all co-authors that they agree to this retraction.

[1] Method development, validation, and stability studies of teneligliptin by RP-HPLC and identification of degradation products by UPLC tandem mass spectroscopy T. N. V. Ganesh Kumar, S. Vidyadhara, Niteen Ashok Narkhede, Y. Sai Silpa \& M. Rajya Lakshmi https://doi.org/10.1186/s40543-016-0099-0

[2] Method development, validation, and stability studies of teneligliptin by RP-HPLC and identification of degradation products by UPLC tandem mass spectroscopy T. N. V. Ganesh Kumar, S. Vidyadhara, Niteen Ashok Narkhede, Y. Sai Silpa \& M. Rajya Lakshmi https://doi.org/10.1186/s40543-016-0107-4

\begin{abstract}
Author details
'Department of Pharmaceutical Analysis, Chebrolu Hanumaiah Institute of Pharmaceutical Sciences, Guntur, Andhra Pradesh 522019, India. ${ }^{2}$ Council for Scientific and Industrial Research (CSIR)-Indian Institute Integrative Medicine, National Institute of Oceanography Regional Centre, Mumbai, India.
\end{abstract}

Published online: 19 May 2020

\section{Reference}

Kumar G, et al. Method development, validation, and stability studies of teneligliptin by RP-HPLC and identification of degradation products by UPLC tandem mass spectroscopy. J Anal Sci Technol. 2016;7:18. https://doi.org/10. 1186/s40543-016-0099-0.

* Correspondence: ganeshtnv@gmail.com

'Department of Pharmaceutical Analysis, Chebrolu Hanumaiah Institute of

Pharmaceutical Sciences, Guntur, Andhra Pradesh 522019, India

Full list of author information is available at the end of the article

\section{Springer Open}

( ) The Author(s). 2020 Open Access This article is licensed under a Creative Commons Attribution 4.0 International License, which permits use, sharing, adaptation, distribution and reproduction in any medium or format, as long as you give appropriate credit to the original author(s) and the source, provide a link to the Creative Commons licence, and indicate if changes were made. The images or other third party material in this article are included in the article's Creative Commons licence, unless indicated otherwise in a credit line to the material. If material is not included in the article's Creative Commons licence and your intended use is not permitted by statutory regulation or exceeds the permitted use, you will need to obtain permission directly from the copyright holder. To view a copy of this licence, visit http://creativecommons.org/licenses/by/4.0/. 